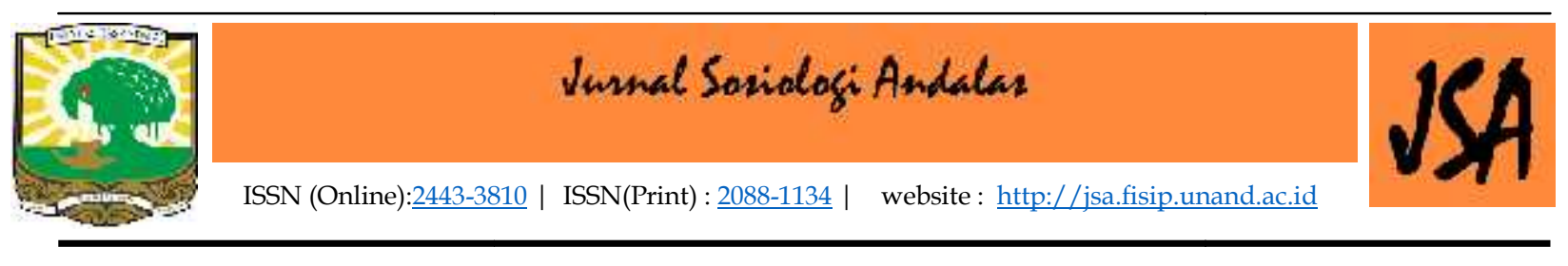

\title{
Perubahan Perilaku Pedagang Pasca Revitalisasi Blok III Pasar Raya Padang
}

\author{
Almuttaqin Suddana \\ Jurusan Sosiologi, FISIP Universitas Andalas \\ Email: almuttaqinsuddana97@gmail.com
}

\begin{abstract}
Article attempts to describe and explain in detail the changes in traders' behavior after Revitalization of Blok III Pasar Raya Padang. Informants were selected using purposive sampling technique and in data collection used observation techniques and in-depth interviews. The results showed an increasingly good physical market change such as the presence of merchant zoning, market floors that had been using ceramics, increasingly good lavatories, better prayer rooms, extensive merchant stalls, cleanliness and market security. Market changes bring changes in the behavior of traders both in serving buyers such as hours of going and going home trading, strategies to serve buyers and how to increase merchant merchant turnover. The better and more organized physical changes make the behavior of traders more orderly and cleaner. There are many ways for traders to dispose of trash, such as throwing trash into the trash can, putting it in a sack, and putting it next to the tavern so that it is not included. Market revitalization influences the relationship between traders before being revitalized which is increasingly distant due to the distance between old traders.
\end{abstract}

Keywords: Change, Behavior, Revitalization.

\section{A. PENDAHULUAN}

Perdagangan merupakan kegiatan tukar menukar barang atau jasa atau keduanya yang berdasarkan kesepakatan bersama bukan pemaksaan. Tempat berlangsungnya kegiatan perdagangan adalah pasar. Pasar secara fisik adalah tempat pemusatan beberapa pedagang tetap dan tidak tetap yang terdapat pada suatu ruangan terbuka atau tertutup atau sebagian terbuka atau sebagian bahu jalan. Polanyi (2003) mengatakan pasar merupakan sebuah institusi sebagai arena praktik transaksi ekonomi berlangsung, dan telah ada sejak manusia mulai mengenal pertukaran dalam pemenuhan kebutuhan hidupnya. Sosiologi memandang pasar sebagai fenomena sosial yang kompleks dengan berbagai macam perangkatnya. Yang mana perangkat pasar sendiri terdiri atas adanya penjual, pembeli, penyalur, suplayer, distributor, dan stakeholder. Pasar merupakan suatu struktur yang padat dengan jaringan sosial atau yang penuh dengan konflik dan persaingan. Pasar jika dilihat dari pendekatan jaringan sosial adalah suatu struktur hubungan antara beberapa aktor pasar, seperti pedagang retail (besar, menengah, dan kecil), pesaing, pemasok (rekanan), distributor, pembelli (pengunjung, pembeli, pelanggan), organisasi pasar (pemerintah, bukan pemerintah, swasta). 
Sejak lama pasar tradisional memegang peranan penting dalam memajukan dan menggerakkan pertumbuhan ekonomi rakyat. Pasar tradisional menurut Kasmir adalah sebagai tempat bertemunya penjual dan pembeli untuk melakukan transaksi. Pasar juga diartikan sebagai suatu mekanisme yang terjadi antara penjual dan pembeli atau tempat pertemuan antara kekuatan permintaan dan penawaran. Pasar tradisional dicirikan dengan terdapatnya hubungan antara pedagang dan pembeli secara langsung. Hubungan pedagang dan pembeli terjadi secara, terangterangan dalam tawar-menawar dan dengan transaksi yang jelas.

Pasar tradisional diasumsikan oleh masyarakat dengan tempat yang kumuh, semrawut, becek, pengap, bau, dan sumpek. Pada daerah-daerah tertentu, pasar tradisional juga sering dituduh sebagai sumber kemacetan, sebab para pedagang sering memanfaatkan sempadan jalan sebagai tempat menggelar barang dagangannya akibatnya laju kendaraan menjadi terganggu. Pasar tradisional yang banyak memiliki kelemahan, pemerintah berupaya melakukan revitalisasi pasar tradisional untuk memvitalkan kembali kondisi pasar yang dulunya pernah vital/hidup, akan tetapi kemudian mengalami kemunduran/degradasi. Revitalisasi pasar yang di lakukan oleh Kementrian Perdagangan di Indonesia mencapai 1023 pasar tradisional yang sudah di revitalisasi pada tahun 2015. Kemudian di tahun 2016, ada 793 pasar tradisional direvitalisasi. Sementara pada 2017 Kemendag merevitalisasi 851 pasar. Lalu, pada 2018, sebanyak 1.544 pasar tradisional dibangun atau direvitalisasi.

Salah satu pasar yang direvitalisasi adalah Pasar Raya Padang. Pasar Raya Padang adalah pasar tradisional terbesar yang menjadi pusat perdagangan utama di Kota Padang. Pemerintah Kota Padang sudah melakukan merevitalisasi bangunan pasar raya melalui pembangunan Pasar Inpres Blok I, II, III dan IV yang menelan biaya Rp 247 miliar. Perubahan Pasar Raya Padang yang dirasakan lebih bersih sekarang dari pada sebelum pasar direvitalisasi karena saluran air yang tersumbat ataupun tidak bagus yang menyebabkan pasar mudah becek dan kotor sudah diperbaiki sehingga kondisi pasar lebih nyaman baik untuk pedagang dan pengunjung pasar. Perubahan kondisi fisik pasar yang sudah baik dari sebelumnya diasumsikan membawa perubahan terhadap perilaku pedagang. Sebelum direvitalisasi perilaku pedagang membuang sampah sembarangan sehingga membuat pasar sebelum direvitalisasi kotor dan jorok yang berdagang dipasar, namun sekarang pedagang lebih menjaga kebersihan pasar dibandingkan sebelum revitalisasi terlihat dengan berkurangnya sampah yang berserakan dilokasi tempat berdagang dimana pedagang membuang sampah pada tempat sampah, dimasukkan ke karung maupun di letakkan disamping kedai, bagi yang membuang sampah sembarangan akan diberi peringatan oleh petugas pasar.

Perubahan perilaku pedagang seperti perubahan dalam meletakan barang dagangan yang berbeda sebelum revitalisasi dimana biasanya pedagang meletakan barang dagangan bisa dalam jumlah banyak dan barang dagangan biasanya bisa distok di dalam kedai, tapi sekarang diletakkan di gudang ataupun distok di rumah. Perbedaan ini dikarenakan perubahan ukuran tempat berdagang yang semakin kecil setelah revitalisasi yang mana ukuran sebelum revitalisasi berukuran 3 meter $^{2} \times 4$ meter $^{2}$, sekarang berukuran 1,5 meter $2 \times 2$ meter $^{2}$. Adanya penurunan omset yang dirasakan pedagang sebelum pasar direvitalisasi. Menurut pedagang perubahan ukuran tempat berdagang juga mempengaruhi dalam melayani pembeli 
dimana agak kesulitan dalam mengambilkan pesanan pembeli dan pedagang terkesan lambat dalam melayani karena barang dagangan yang ditumpuk hampir memenuhi tempat berdagang sehingga agak kesulitan dalam ruang gerak pedagang mengambilkan pesanan pembeli.

Penelitian ini melihat perubahan perilaku pedagang pasca revitalisasi Pasar Raya Padang. Perilaku pedagang adalah suatu tanggapan atau reaksi pedagang terhadap rangsangan atau lingkungan yang ada di sekitar. Perilaku pedagang juga merupakan sebuah sifat yang dimiliki oleh setiap orang pedagang, untuk menangkap reaksi yang telah diberikan oleh lingkungan terhadap keadaan yang telah terjadi sekarang. Banyaknya perilaku pedagang, mengakibatkan juga banyaknya tanggapan tentang apa yang terjadi. Perubahan prilaku pedagang diasumsikan peneliti karena adanya revitalisasi pasar.

\section{B. METODE PENELITIAN}

Metode yang digunakan dalam penelitian ini adalah metode kualitatif. Metode kualitatif dipilih dengan tujuan untuk mengupayakan suatu penelitian dengan menggambarkan secara sistematis, faktual dan akurat mengenai fakta-fakta dari suatu peristiwa serta sifat-sifat terentu. Afrizal (2014 : 13) yang mendefinisikan metode kualitatif sebagai metode penelitian ilmu-ilmu Sosial yang mengumpulkan dan menganalisis data berupa kata-kata (lisan maupun tulisan) dan perbuatanperbuatan manusia serta peneliti tidak berusaha menghitung atau mengkuantifikasikan data kualitatif yang telah diperoleh dan dengan demikian tidak menganalisis angka-angka. Metode kualitatif ini digunakan untuk mendeskripsikan mengenai perubahan perilaku pedagang pasca revitalisasi blok III Pasar Raya Padang. Sesuai dengan penjelasan diatas, dibutuhkan data berupa katakata dari informan atau aktor-aktor yang telibat.

\section{Pendekatan dan Tipe Penelitian}

Pendekatan mengacu pada perspektif teoritis yang dipakai oleh para peneliti dalam melakukan penelitian. Tipe penelitian yang dipakai dalam rencana penelitian ini adalah tipe penelitian deskriptif yakni penelitian yang bermaksud memberi gambaran mendalam, sistematis, faktual dan akurat mengenai fakta serta hubungan antara fenomena yang diselidiki. Penelitian yang bersifat deskriptif ini berusaha menggambarkan dan menjelaskan secara rinci mengenai perubahan perilaku pedagang pasca Revitalisasi Blok III Pasar Raya Padang.

\section{Informan Dan Teknik Pemilihan Informan}

Afrizal (2014 : 139) menambahkan pengertian informan penelitian yaitu orang yang memberikan informasi baik tentang dirinya maupun orang lain atau suatu kejadian atau suatu hal kepada peneliti atau pewawancara mendalam. Kata informan harus dibedakan dari kata responden. Informan adalah orang-orang yang akan memberikan informasi baik tentang dirinya maupun orang lain atau suatu kejadian, sedangkan responden adalah orang-orang yang hanya menjawab pertanyaan-pertanyaan pewawancara bukan memberikan informasi atau keterangan. Informan dalam penelitian ini adalah pedagang, petugas dinas pasar dan pembeli.

Jumlah informan yang diambil dalam penelitian ini berdasarkan asas kejenuhan data, ini berarti informasi dari informan-informan sebelumnya dirasakan 
menyerupai maksud dari permasalahan maka proses pengumpulan data dapat dihentikan, karena telah menjawab pertanyaan penelitian. Adapun maksud dari kriteria-kriteria tertentu yang telah peneliti tetapkan berguna untuk memberikan informasi yang sesuai dengan tujuan penelitian.

Penetapan kriteria-kriteria informan yaitu; pedagang pasar raya blok III yang berdagang sebelum dan sesudah revitalisasi pasar, pedagang yang berdagang di basement, dan lantai I karena jumlah pedagang lebih banyak disana, pedagang di kelompokkan berdasarkan zonasi dagangan pedagang yang telah memiliki keluarga, pegawai tata kelola Dinas Pasar Raya Padang, Petugas kebersihan dan satpol PP yang bertugas di area blok III Pasar Raya Padang, Pembeli langganan yang sering membeli barang ke pedagang blok III Pasar Raya Padang.

\section{Data yang Diambil}

Menurut Lofland (dalam Moleong, 2004 : 112), sumber utama dalam penelitian kualitatif adalah kata-kata dan tindakan. Selebihnya hanyalah data tambahan seperti dokumen, dan lain-lain. Dalam penelitian ini, data didapat melalui dua sumber, yaitu data primer dan data sekunder. Data primer atau data utama merupakan data atau informasi yang didapatkan langsung dari informan penelitian dilapangan. Data sekunder yaitu data tambahan yang diperoleh melalui penelitian pustaka yakni pengumpulan data yang bersifat teori yang berupa pembahasan tentang bahan tertulis, literatur hasil penelitian

\section{Teknik Pengumpulan Data}

Teknik Observasi atau pengamatan dapat didefinisikan sebagai perhatian yang terfokus terhadap kejadian, gejala, atau sesuatau.peneliti melakukan pengamatan terhadap gejala-gejala dan kejadian-kejadian sebagaimana terjadi.

Wawancara mendalam adalah pertemuan langsung dengan informan penelitian serta mengumpulkan informasi dari hasil percakapan dengan informan. Maksud mengadakan wawancara menurut Lincoln dan Guba seperti yang dikutip oleh Moleong (2004:135) adalah mengkonstruksikan mengenai orang, organisasi, perasaan, motivasi, tuntutan, kepedulian dan lain-lain.

\section{Tinjauan Pustaka}

Penelitian ini yang digunakan adalah paradigma perilaku sosial. Paradigma ini dikemukakan oleh B.F Skinner. Menurut Skinner obyek studi sosiologi yang konkrit-realistis itu adalah perilaku manusia yang nampak serta kemungkinan perulangannya (behavior of man and contingenencies of reinforcement) (Ritzer, 2013: 70). Menurut paradigma perilaku sosial, pokok persoalan sosiologi adalah tingkah laku individu yang berlangsung dalam hubungannya dengan faktor lingkungan yang menghasilkan akibat-akibat atau perubahan dalam faktor lingkungan menimbulkan perubahan terhadap tingkah laku. Jadi terdapat hubungan fungsional antara tingkah laku dengan perubahan dengan perubahan yang terjadi dalam lingkungan aktor.

Teori yang dipakai di dalam penelitian ini yaitu teori Behavioral Sociology, yang Behavioral Sociology dibangun dalam rangka menerapkan prinsip psikologi perilaku kedalam sosiologi. Teori ini memusatkan perhatiannya kepada hubungan antara akibat dari tingkah laku yang terjadi di dalam lingkungan aktor dengan tingkah laku aktor. Ini berarti bahwa teori ini berusaha menerangkan tingkah laku 
yang terjadi di masa sekarang melalui kemungkinan akibatnya yang terjadi di masa yang akan datang. Yang menarik perhatian adalah hubungan historis antara akibat tingkah laku yang terjadi dalam lingkungan yang terjadi di masa sekarang. Dengan mengetahui apa yang di peroleh dari suatu tingkah laku nyata di masa lalu akan dapat diramalkan apakah seseorang aktor akan bertingkah laku yang sama ( mengulanginya) dalam situasi sekarang.

Jika dihubungkan dengan penelitian tentang perubahan perilaku pedagang pasca Revitalisasi Pasar Raya Padang Blok III, bahwa pedagang berperilaku karena adanya interaksi antara pedagang dengan lingkungannya, maksudnya adalah lingkungan dapat mempengaruhi perilaku seseorang dalam berprilaku. Sebagaimana yang didapatkan melalui observasi adanya perubahan perilaku pedagang setelah dilakukannya revitalisasi pasar. Perubahan luas lapak pedagang yang lebih kecil dari lapak sebelum di revitalisasi 2016 dimana lapak pedagang lebih besar. Perubahan lapak setelah Revitalisasi yang biasanya luas lapak atau kios 3x4 menjadi 1,5x2. Akibat lapak yang lebih kecil, penataan barang pedagang tidak mencukupi bahkan pedagang mempergunakan jalan bagi pembeli untuk meletakan dagangannya, walau sudah ada garis pembatas. Hal ini akan mempengaruhi jual beli pedagang dalam memenuhi kebutuhan konsumen. Jumlah lapak atau kios semakin banyak setelah revitalisasi sehingga jumlah pedagang semakin banyak pula. Akibatnya tinggi nya tingkat persaingan antar pedagang dalam menawarkan dagangannya.

\section{Pengertian Perubahan}

Perubahan merupakan satu wujud nyata dari kehidupan yang mampu mendorong atau memotivasi sesorang untuk mengubah Sesuatu menjadi bebeda dari sebelumnya melalui sebuah proses yang dapat terjadi dimana saja dan kapan saja. Perubahan dapat membuat sesorang mampu menciptakan atau merubah sesuatu sesuai dengan tututan situasi dan kondisi keluarga, lingkungan dan masyarakat setempat.

\section{Pendapat Ahli Tentang Perilaku}

Skiner seorang ahli psikologi, merumuskan bahwa perilaku merupakan respon atau reaksi seseorang terhadap rangsangan dari luar. Skiner membedakan perilaku tersebut menjadi dua jenis proses yang diantaranya ialah Respondent Respon atau Reflexsive, yakni respon yang ditimbulkan oleh rangsanganrangsangan (stimulus) tertentu. Stimulus semacam ini disebut electing stimulatonkarena menimbulkan respon-respon yang relatif tetap. Sedangkan proses yang kedua ialah Operant Responatau Instrumental Respon, yakni respon yang timbul dan berkembang kemudian diikuti oleh stimulus atau perangsang tertentu. Perangsang ini disebut reinforcing stimulus atau reinforce karena dapat memperkuat respon.

\section{Pengertian tentang Pedagang}

Pedagang adalah orang atau institusi yang memperjualbelikan produk atau barang, kepada konsumen baik secara langsung maupun tidak langsung. Sosiologi ekonomi membedakan pedagang berdasarkan penggunaan dan pengelolaan pendapatan yang dihasilkan dari perdagangan dan hubungannya dengan ekonomi 
keluarga. Pedagang sebagai penghubung antara produsen sebagai penghasil barang dengan konsumen sebagai pemakai barang atau jasa.

\section{Pengertian Perilaku Pedagang}

Perilaku pedagang adalah suatu tanggapan atau reaksi pedagang terhadap rangsangan atau lingkungan yang ada di sekitar. Perilaku pedagang juga merupakan sebuah sifat yang dimiliki oleh setiap orang pedagang, untuk menangkap reaksi yang telah diberikan oleh lingkungan terhadap keadaan yang telah terjadi sekarang. Banyaknya perilaku pedagang, mengakibatkan juga banyaknya tanggapan tentang apa yang terjadi.

Perilaku pedagang harus mengetahui hal-hal yang diarahkan untuk memuaskan kebutuhan dan keinginan pembeli dengan melalui proses pertukaran. Proses pertukaran melibatkan kerja, penjual harus mencari pembeli, menemukan dan memenuhi kebutuhan pembeli, merancang produksi yang tepat, menentukan harga yang tepat, menyimpan dan mengangkutnya, mempromosikan produk tersebut, menegosiasikan dan sebagainya, semua kegiatan ini dilakukan untuk memperoleh pembeli yang lebih banyak dan dagangan agar cepat terjual.

\section{Konsep Pasar}

Belshaw (2003) menulis bahwa pasar adalah tempat penjual dan pembeli saling bertemu dan mengadakan pertukaran. Akibatnya adanya perubahan sosial dan budaya dikalangan masyarakat, pasar tidak lagi semata-mata merujuk pada suatu tempat, tetapi memiliki dimensilain yaitu di interpretasikan keadaan sistem budaya yang bermakna yang memiliki simbol-simbol sendiri. Pasar adalah sebuah institusi, tempat pertemuan antara pembeli dan penjual; suatu peristiwa yang terbentuk dan memiliki budaya yang khas melibatkan banyak orang dalam tindakan dan hubungan sosial, yang membentang pada sejumlah tingkatan.

\section{Revitalisasi Pasar Tradisional}

Revitalisasi pasar merupakan pelaksanaan dari Undang-undang nomor 7 tahun 2014 tentang Perdagangan, pasal 13 ayat (1), (2) dan (3) yang mengamanatkan bahwa Pemerintah bekerja sama dengan Pemerintah Daerah melakukan pembangunan, pemberdayaan, dan peningkatan kualitas pengelolaan pasar rakyat guna peningkatkan daya saing dalam bentuk pembangunan dan/ atau revitalisasi pasar tradisional; implementasi manajemen pengelolaan yang profesional; fasilitasi akses penyediaan barang dengan mutu yang baik dan harga yang bersaing; dan fasilitasi akses pembiayaan kepada pedagang pasar di pasar rakyat.

\section{HASIL DAN PEMBAHASAN}

\section{Kondisi Fisik Pasar Sebelum Revitalisasi}

Kondisi fisik Pasar Raya Padang Blok III sebelum revitalisasi adalah dimana kondisi fisik bangunan pasar yang sudah tua dan tidak layak pakai. Dinding bangunan sebagian besar ada yang mengalami retak di karenakan gempa tahun 
2009. Lantai dasar bangunan pasar menggunakan cor semen yang tidak rata dan berlobang sehingga sering becek saat hujan. Kondisi ini membuat kondisi pasar tidak bersih dan mudah kotor. Kondisi listrik sebelum revitalisasi pemakaian listrik satu berdua dengan pedagang yang berdekatan, kondisi pasar juga kurang terang karena lampu di sekitar jalan blok III sudah banyak yang rusak dan mati, dan juga iuran fasilitas listrik memberatkan para pedagang yang di bayar perbulan kepada dinas Pasar Raya. Kondisi kebersihan pasar sebelum revitalisasi kondisi pasar kurang bersih karena banyaknya sampah pedagang yang berserakan dan terdapat petugas kebersihan pasar yang hanya membuang sampah setiap dua hari sekali. Sebelum revitalisasi kondisi WC yang kurang bersih dan tempat sholat pedagang kecil dimana terdapat 2 WC dan 2 tempat sholat, sehingga pedagang harus bergantian dalam melaksanakan ibadah. Setelah revitalisasi kondisi WC yang sudah bersih dan tempat sholat pedagang yang lebih besar terdapat tambahan WC dan tempat sholat, 4 WC dan 4 tempat sholat.

\section{Kondisi Fisik Pasar Sesudah Revitalisasi}

Revitalisasi pasar yang diperbaiki di blok III sehingga membuat kondisi fisik pasar yang bagus sesudah direvitalisasi pasar. Kondisi fisik Pasar Raya Padang Blok III setelah revitalisasi adalah dimana kondisi fisik bangunan pasar sudah diperbaiki sehingga bangunan pasar menjadi kokoh kembali. Setelah direvitalisasi sistem saluran air bangunan pasar yang sudah bagus, air mengalir dengan lancar sehingga membuat pasar tidak becek saat hujan . Setelah revitalisasi bagian dasar lantai sebagian besar sudah berkeramik.

Setelah revitalisasi sudah adanya zonasi dagangan dimana pedagang sayur berada di lantai basement, dan pedagang p\&d berada di lantai 1. Ukuran tempat berdagang semakin kecil ber ukuran 1,5 × $2 \mathrm{~m}^{2}$. Setelah revitalisasi daya listrik lebih besar sehingga keadaan dalam pasar lebih baik. Lampu jalan sekitaran blok III yang sudah diperbaiki dan ditambah membuat jalan sekiran blok III menjadi terang dan bagus. Kondisi pasar lebih terang lebih terlihat jelas dalam penataan barang, dan iuran listrik bedasarkan token yang dibayar oleh pedagang satu listrik 1 pedagang. Setelah revitalisasi kondisi pasar sudah bersih terdapat petugas kebersihan yang membuang sampah setiap pagi dan sore. Kondisi WC yang sudah bersih dan tempat sholat pedagang yang lebih besar terdapat tambahan WC dan tempat sholat, 4 WC dan 4 tempat sholat.

\section{Perilaku Pedagang Sebelum Revitalisasi Pasar Padang Blok III.}

Jam Pergi berdagang pedagang dulu sebelum revitalisasi pergi berdagang di pagi hari karena apabila pergi lebih awal kondisi penerangan pasar yang tidak memadai dan gelap membuat pedagang kesusahan dalam menyusun dagangan dan juga pembeli yang datang ke pasar jam 7 pagi ketika kondisi langit yang sudah sedikit terang. Pembeli dulu datang pagi jam 7 karena kondisi pasar kurang terang dan susah dalam berbelanja. Pembeli langganan yang datang pagi hari untuk membeli keperluan dagangan dirumah. Pembeli yang datang jam 7 pagi hari dikarenakan kondisi pasar yang dini hari masih gelap karena penerangan pasar yang kurang seperti lampu jalan sekitaran blok III yang tidak mencukupi.

Melayani pembeli adalah kiat-kiat atau usaha yang dilakukan pedagang dalam melayani pembeli agar pembeli semakin nyaman. Perubahan pasar setelah 
revitalisasi membawa perubahan perilaku pedagang dalam melayani pembeli. adanya kemudahan dalam mengambilkan barang dagangan untuk pembeli sebelum pasar di revitalisasi. Dalam melayanai pembeli dulu cepat, mudah karena tempat berdagang besar yang ukurannya $3 \times 4 \mathrm{~m}^{2}$ karena pedagang leluasa gerak dalam mengambilkan barang untuk pembeli dan tidak terkesan lelet dalam mengambilkan barang pembeli yang banyak. Menyusun dagangan juga mudah dengan tempat yang besar.

Persediaan barang adalah barang-barang yang disimpan untuk digunakan atau untuk dijual pada masa atau periode yang akan datang. Persediaan barang menentukan dalam kelancaran penjualan, maka persediaan barang harus bisa dikelolah dengan baik. Pedagang sebelum revitalisasi menstok barang dagangan di tempat berdagang saja. Tempat berdagang yang besar ukuran $3 \times 4$ meter membuat pedagang bisa menstok barang dengan jumlah yang banyak.

Memberikan bonus adalah memberikan hal lebih jika seseorang membeli produk atau dagangan baik itu kepada langganan tetap ataupun pembeli dalam jumlah banyak. perilaku pedagang dalam menaikan omset dengan memberikan bonus kepada pelanggan tetap yaitu dengan memberikan potongan harga kepada pembeli langganan dari harga diatas modal pedagang sedikit, sehingga hanya mendapatkan untung sedikit, memberikan lebihan barang dalam memberikan banyak seperti memberikan tambahan gula sekilo, dan juga pedagang dalam memberikan bonus untuk pelanggannya berupa paketan lebaran ketika lebaran datang seperti sirup Abc, Marjan dan minuman keleng lainnya. Dan juga pedagang bentuk bonus yang diberikan kepada pembeli adalah dengan menghadiri pernikahan dari keluarga pelanggannya apabila pedagang diundang.

Sebelum adanya revitalisasi hubungan antara pedagang sangat dekat. Tempat pedagang dulu sebelum revitalisasi dekat. Bentuk kedekatan hubungannya seperti sering mengobrol satu sama lain mengenai barang dagangan, mengenai perpolitikan dan juga kehidupan sehari-hari yang dirasakan. Selain itu sesama pedagang juga saling menunjungi ketika adanya acara keluarga seperti pernikahan dan kematian. Hubungan pedagang sebelum revitalisasi. Hubungan yang sebelum revitalisasi sangat dekat, Hubungan yang dekat antara pedagang lama dirasakan dengan adanya interaksi dalam sehari-hari seperti mengobrol, saling mengunjungi ketika adanya pesta pernikahan dan pergi berziarah ketika adanya kematian.

\section{Perubahan Perilaku Pedagang Setelah Revitalisasi Pasar Padang Blok III}

Perubahan pergi dan pulang berdagang yang dilakukan pedagang setelah revitalisasi pasar. Setelah direvitalisasi pasar semakin terang, dan jalan semakin bagus memudahkan bagi pedagang dalam menyusun barang dagangannya. Dan juga karena penerangan pasar yang sudah bagus, membuat pembeli datang dipagi hari dan mudah dalam berbelanja. Perubahan dalam jam pergi dan pulang yang berlangsung dalam hubungannya dengan pembeli yang datang, menyebabkan perubahan dalam tingkah laku pedagang dalam berdagang baik pedagang yang datang lebih. Perubahan revitalisasi dengan penerangan pasar yang sudah bagus membuat pembeli datang lebih awal ke pasar.

Perubahan pasar setelah revitalisasi membawa perubahan terhadap kerja pedagang dalam melayani pembeli. tempat pedagang yang semakin kecil setelah direvitalisasi mempengaruhi dalam perilaku pedagang dalam meletakkan barang 
dagangan yang semakin susah dan harus di susun rapi agar muat dan barang dagangan diletakkan sedikit kedepan agar terlihat oleh pembeli yang lewat. Dalam mengambilkan belanjaan pembeli setelah revitalisasi agak susah dan kerepotan dikarenakan tempat berdagang yang semakin kecil tadi membuat pedagang terkadang lambat dalam mengambilkan barang belanjaan pembeli. berbeda dengan sebelum revitalisasi yang mudah dalam mengambilkan barang belanjaan membuat pedagang cepat dalam mengambilkan belanjaan pembeli.

Perubahan pasar setelah revitalisasi membawa perubahan terhadap perilaku pedagang dalam menstok barang. Sebelum revitalisasi pedagang menstok barang tempat berdagang karena ukuran tempat berdagang besar. Setelah revitalisasi ukuran tempat berdagang semakin kecil dan membuat pedagang harus cepat dalam mesntok barang dagangan. Pedagang juga mesntok barang dagangan di rumah karena tidak muat di tempat berdagang. selin itu pedagang karena pembeli yang ramai setelah revitalisasi pasar pedagang menambah dagangan yang dijual untuk meningkatkan omset penjualan.

Adanya peningkatan pelanggan dari sebelum revitalisasi pasar dan sesudah revitalisasi pasar. memberikan bonus pelanggan seperti memberikan potongan harga dari harga semula, kalau tidak memberikan lebih barang satu atau dua. Pedagang juga memberikan sirup, minuman kaleng ketika lebaran dan juga barang belanjaannya diantarkan kemobil atau sepeda motor pelanggan. Perbedaan setelah revitalisasi pasar perilaku pedagang dalam memberikan THR lebih banyak, karena jumlah pelanggan bertambah dan pengeluaran untuk THR juga bertambah yang mana dari 1 juta menjadi 1.5 juta. Perubahan lain juga dilihat dari penambahan jumlah karyawan dalam mengantarkan barang dagangan pembeli.

Sebelum adanya revitalisasi hubungan antara pedagang sangat dekat. Bentuk kedekatan hubungannya seperti sering mengobrol satu sama lain mengenai barang dagangan, mengenai perpolitikan dan juga kehidupan sehari-hari yang dirasakan. Selain itu sesama pedagang juga saling menunjungi ketika adanya acara keluarga seperti pernikahan dan kematian. Namun setelah revitalisasi, hubungan kedekatan itu sudah jarang bahkan tidak ada lagi, karena setelah revitalisasi tempat pedagang sudah saling berjauhan dan tempat berdagang tidak sama sebelum direvitalisasi karena adanya system pencabutan lot dalam mendapatkan tempat berdagang setelah revitalisasi. Adanya jarak yang cukup jauh antara sesama pedagang lama membuat jarangnya adanya interaksi antara sesama pedagang.

\section{Harapan Pedagang Terhadap Revitalisasi}

Harapan pedagang agar pedagang lebih diikut seertakan dalam perencanaan pembangunannya dan juga harapan pedagang agar pelayanan pasar lebih ditingkatkan lagi, baik itu wc, tempat sholat, keamaanan, kebersihan dan ketertibannya. Salah satu tujuan dari revitalisasi adalah meningkatkan pendapatan pedagang. Apabila pedagang nyaman dan pembeli nyaman dalam berbelanja maka tujuan revitalisasi berhasil. Diharapkan petugas dinas pasar lebih mendengarkan keluhan ataupun masukan pedagang untuk kebaikan pasar kedepannya.

\section{KESIMPULAN}

Penelitian ini bertujuan untuk mendeskripsikan perilaku pedagang dalam melayani pembeli dan menaikan omset pasca revitalisasi Pasar Raya Padang blok 
III, mendeskripsikan perilaku pedagang dalam menyikapi masalah kebersihan lapak pasca revitalisasi Pasar Raya Padang blok III. Dari hasil penelitian dan analisa data yang telah dilakukan, maka dapat disimpulkan bahwa:

1. Perubahan pasar membawa perubahan perilaku pedagang baik dalam melayani pembeli seperti jam pergi dan pulang berdagang, strategi melayani pembeli dan cara menaikan omset pedagang.

2. Perubahan fisik yang semakin bagus dan tertata membuat perilaku pedagang semakin tertib dan bersih. Banyak cara pedagang dalam membuang sampah seperti membuang sampah ke tong sampah, memasukanya ke karung, dan meletakkan disamping kedai agar tidak bersertakan.

3. Revitalisasi pasar berdampak terhadap hubungan antara pedagang sebelum direvitalisasi yang semakin jauh dikarena adanya jarak antara pedagang lama.

4. Harapan pedagang terhadap revitalisasi adalah agar diikut sertakan dalam perencanaan pembangunan pasar kedepannya dan lebih meningkatkan sarana dan prasarana pelayanan pasar

\section{E. UCAPAN TERIMAKASIH}

Penulis mengucapkan terimakasih kepada seluruh informan di Pasar Raya Blok III yang telah bersedia mengalokasikan waktunya selama proses penelitian. Penulis juga mengucapkan ribuan terimakasih kepada para dosen pembimbing yang telah mengarahkan dan menjadi mentor selama pelaksanaan penelitian ini.

\section{DAFTAR PUSTAKA}

\section{Buku :}

Afrizal. 2005. Pengantar Metode Penelitian Kualitatif: dari Pengertian Sampai Penuliasan Laporan. Unand Padang. Laboratorium Sosiologi FISIP 2014. Metode Penelitian Kualitatif. Jakarta : PT RajaGrafindo Persada.

Anies. 2006. Waspada Ancaman Penyakit Tidak Menular Solusi Pencegahan Dari Aspek Perilaku \& Lingkungan. Jakarta: PT Elex Media Komputindo.

Bungin, Burhan. 2012. Metodologi penelitian kualitatif. Jakarta: PT.RajaGrafindo Persada

Damsar, 2005. Sosiologi Pasar. Padang. Laboratorium Sosiologi. FISIP - UA.. 2009. Pengantar Sosiologi Ekonomi. Jakarta: Kencana

Departemen Pendidikan Nasional. 2000. Kamus Besar Bahasa Indonesia Edisi Ketiga. Jakarta: Gramedia Pustaka Cipta.

Emzir. 2011. Analisis Data Metodologi Penelitian Kualitaif. Jakarta: Rajawali Pers. Eko Sujatmiko. 2014. Kamus IPS. Surakarta: Aksara Sinergi media.

Fuad, M, dkk. 2000. Pengantar Bisnis. Jakarta: PT Gramedia Pustaka Umum.

Heri, Purwanto. 1999. Pengantar Prilaku Manusia Untuk Keperawatan, Jakarta : Kedokteran EGC.

Kasmir. 2007. Dasar- Dasar Perbankan. PT. Raja Grafindo Persada, Jakarta.

Kuper, Adam, dan Jessica, Kuper. 2000. Ensiklopedia Ilmu-Ilmu Sosial Edisi Kedua. Jakarta: PT. RajaGrafindo Persada.

Moleong, Lexy J. 2004. Metodologi Penelitian Kualitatif Edisi Revisi. Penerbit Rosda. 
Notoatmodjo, S. 2010. Ilmu Perilaku Kesehatan. Jakarta : Rineka Cipta.

Ritzer, George. 1985. Sosiologi Berparadigma Ganda. Jakarta : PT RajaGrafindo Persada.

Ritzer, George. 2013. Sosiologi Berparadigma Ganda. Jakarta : PT RajaGrafindo Persada.

Sanderson, Stephan K. 2011. Makrososiologi. Jakarta: Rajawali Pers.

Singarimbun, MASRI dan Sofyan Efendi. 1989. Metode Penelitian Survival. Jakarta: LP3ES.

Soekanto, Soerjono. 1985. Kamus Sosiologi Industri. Jakarta : PT Raja Grafindo Persada. 2012. Sosiologi Suatu Pengantar. Jakarta : Rajawali Pers.

Subekti, R. 2005. Kamus Hukum. Jakarta : Pradnya Paramita.

Sugiyono. 2010. Metode Penelitian Kuantitatif dan Kualitatif dan RED.Bandung: Alfabeta.

Sukirno, Sadono. 2005. Mikro Ekonomi Teori Pengantar Edisi Ketiga. Jakarta: PT.RajaGrafindo Persada.

Walgito, Bimo. 2003. Psikologi Sosial Suatu Pengantar. Andi Offset : Yogyakarta.

Zusmelia, 2005.Persistensi Pasar Nagari Di Minangkabau Dalam Menghadapi Tekanan Ekonomi Global, Bogor; Program Studi Sosiologi Perdesaan Pascasarjana, proposal, Institut Pertanian Bogor.

\section{Skripsi :}

Kusnia, Siti Mina. 2015. " Perilaku pedagang di pasar tradisional Ngaliyan Semarang". Semarang : Skripsi Jurusan Ekonomi Isllam UIN Walisongo Semarang.

Lestari, Shinta. 2016. "Perilaku Pedagang Dalam Membuang Sampah (Studi di kawasan Bandar Jaya Plaza Kelurahan Bandar Jaya Timur, Kecamatan Terbanggi Besar, Kabupaten Lampung Tengah". Lampung : Skripsi Jurusan Sosiologi UNILA.

\section{Internet :}

(http:/ / digilib.unila.ac.id/20984/15/BAB\%20II.pdf). Diakses 14 Juli 2019 (http:/ / eprints.undip.ac.id/62926/1/08_DAHNIAR.pdf). Diakses 21 Maret 2019 (https:/ / media.neliti.com). Diaksek 21 Maret 2019

(https:/ / pasarsayuronline.wordpress.com/tag/kelebihan-dan-kelemahan-pasartradisional-dengan-modern/). Diakses 21 Maret 2019

(https:/ / tirto.id/revitalisasi-pasar-tradisional-kemendag-anggarkan-rp11-triliundhpF). Diakses 21 Maret 2019

http:/ / ews.kemendag.go.id. Diakses 11 Juni 2019

http://jdih.Kemendag.go.id/backend/image/old/1998/01/21/lembaga-lembagausaha-perdagangan-id-1390816831.pdf) . Diakses 11 Juni 2019

http://repositori.uin-alauddin.ac.id. Diakses 3 Juni 2018

https:/ /id.wikipedia.org/wiki/Perdagangan. Diakses 29 Mei 2018 